\title{
Demarcating Popular Education with Government Subsidies: Sweden 1911-1991
}

\author{
Samuel Edquist
}

\begin{abstract}
By analysing the regulating mechanisms of state subsidies to Swedish institutions generally considered mediating "popular education" during the twentieth century, it is argued that a tension has been developed between two parallel notions of popular education. A narrower ideal popular education-emphasising non-formality and independence - has been discursively nurtured along with a broader organisational popular education, denoting the de facto institutions that have received government funding, primarily the folk high schools and study associations. It is argued that the organisational popular education is a reality in itself, spanning over border zones between, for example, non-formal and formal education. Furthermore, an argument against using "popular education" as an analytical concept is put forth, since it is overly contested. Rather, it is promoted as a discursive construct that has formed real organisational structures with their own logic, which cannot be denoted by words such as non-formal adult education.
\end{abstract}

Keywords

popular education, non-formal adult education, economics of education, cultural politics, Sweden

\section{Introduction}

In Sweden, institutions generally known to promote popular education (folkbildning) are often regarded as an important part of the success story of twentieth century Sweden as an example of democracy and social equality. ${ }^{1}$ Popular education is-at least in political and scholarly contexts ${ }^{2}$ - considered a free form of education, independent of the state, and a non-hierarchical arena outside the regular public school system.

In reality, popular education institutions do not always fit into that ideal, and the same can be said regarding their level of independence from the state. Government subsidies have largely shaped the size and content of these educational institutions. In 1872, owing to a parliamentary decision, folk high schools received regular funding, followed by public lectures in 1884, public libraries in 1905 and study circles in 1947 (which started receiving funding indirectly in 1912, if they supported a libra-

1 For example, in the government bill of 1991 on popular education: prop. 1990/91:82, 6-7. See the reference section for explanations of the abbreviations of this and other categories of state publications.

2 In a more "everyday" understanding, in Sweden, "popular educator" is rather associated with journalists, scholars or scientists that, as individuals, possess excellent abilities in transmitting knowledge to the general public.

Samuel Edquist is Associate Professor in Archival Science and History, Södertörn University and Uppsala University, Sweden.

Email: samuel.edquist@sh.se 
ry). However, the subsidies were conditioned, as a number of demands had to be filled in order to receive the funds. Thus, they functioned as regulatory mechanisms. In this article, I will focus on one such mechanism: the ways subsidies have come to influence the entire concept of popular education in Sweden.

As will be shown, some institutions and practices have been included in a discursively shaped popular education area. A tension between a narrower ideal popular education stressing non-formality and free and democratic forms, independence from the state and a broader organisational popular education has developed. The latter consists of the institutions that have received funding for popular educationprimarily the folk high schools and study associations. ${ }^{3}$

I will highlight the tendencies that emerged at the beginning of the 1910s-a time of some major popular educational reforms, soon followed by other crucial changes, such as the adoption of general suffrage and the build-up of a modern, bureaucratic welfare state. The analysis ends in 1991, when the system of state subsidies changed radically. Some overall targets replaced most of the detailed regulations for subsidies, and the distribution of subsidies shifted from governmental agencies to a semi-public council (Folkbildningsrådet), composed by the popular education institutions themselves. This was part of a general shift in education policies from traditional bureaucratic regulation to management by objectives. ${ }^{4}$

The concept of popular education is a topic of vivid discussion in international research. For example, at the 2009 ISCHE (International Standing Conference on the History of Education) in Utrecht, it was the main theme. The international discussions of the popular education concept are coloured by different national settings. There is a narrow definition that seems prominent in Anglo-Saxon countries, which is rather restrictive, as it excludes most activities that cannot be described as being outside the state and having emancipatory purposes. ${ }^{5}$ On the other hand, there is a wide definition that claims that mass educational initiatives of the nineteenth century-including mass schooling — should be included. ${ }^{6}$ Finally, there is a definition that falls somewhere between these two poles, reflecting the situation in, for example, France and Scandinavia. While it excludes public schools, contrary to the narrow definition, it includes non-formal leisure and cultural activities for the youth, and without any demands for political or social radicalism. ${ }^{7}$ Another typical feature, when the demarcation of the concept is not explicitly made, is to associate popular education with progressive forces in the Enlightenment tradition. ${ }^{8}$

3 The equivalence between folkbildning and the organisations receiving state subsidies has been touched upon by, for example, Erling Bjurström, "Bildning och demokrati," in Bildning och demokrati: Nya vägar i det svenska folkbildningslandskapet, ed. Erling Bjurström and Tobias Harding (Stockholm: Carlssons, 2013), 46-47.

4 Prop. 1990/91:127; SFS 1991:977; cf. Donald Broady, ed., Skolan under 1990-talet: Sociala förutsättningar och utbildningsstrategier: Rapport till kommittén Välfärdsbokslut (Uppsala: Uppsala universitet, 2000).

5 E.g., Jim Crowther, "Reflections on Popular Education in the UK and Sweden," in Popular Education, Power and Democracy: Swedish Experiences and Contributions, ed. Ann-Marie Laginder, Henrik Nordvall and Jim Crowther (Leicester: Niace, 2013), 261-62.

6 Sjaak Braster, "The People, the Poor, and the Oppressed: The Concept of Popular Education through Time," Paedagogica Historica 47, no. 1-2 (2011), 1-5.

7 Alejandro Tiana Ferrer, "The Concept of Popular Education Revisited - Or What Do We Talk about When We Speak of Popular Education," Paedagogica Historica 47, no. 1-2 (2011), 15-31.

8 E.g., Tom Steele, Knowledge is Power! The Rise and Fall of European Popular Educational Movements 1848-1939 (Bern: Peter Lang, 2007). 
The general meaning of the Swedish term "folkbildning" is close to the "middle" definition of popular education. ${ }^{9}$ Both "popular education" and "folkbildning" are equally contested, with an inherent vagueness, since they lean on the "the people"-for an analytical purpose, a tricky word to say the least. Therefore, I conclude that "popular education" is the most appropriate English translation of the Swedish word "folkbildning". In my view, other alternatives that are often put forward, such as non-formal adult education, ${ }^{10}$ liberal adult education, ${ }^{11}$ or simply "folkbildning" untranslated, do not fully convey its actual meaning. ${ }^{12}$ The vagueness of the popular education concept is actually beneficial for this study, since I primarily regard it as a discursive construct-an "imagined concept" just as the "nation" or "the people", 13 something to be analysed rather than something to build the analysis upon.

As I will show, truly analytical concepts such as non-formal education would risk overemphasising the boundaries towards formal education, as well as those between "education" and "non-education". Instead, those boundaries are fluent, and have often been crossed by de facto activities within Swedish popular education. In my opinion, these border crossings are important and interesting phenomena as such. As I will show, many of the activities within organisational popular education in Sweden should from an analytical viewpoint rather be defined as formal adult education, for example.

In the following, I argue that popular education has been shaped through the state subsidy system, including constant negotiations regarding the boundaries towards other fields. Among other benefits of this viewpoint, I hope that a more realist picture of popular education is obtained. For long, research and history writing have tended to focus on those aspects of popular education that are "unique", with truly non-formal educational forms, whereas its elements of vocational training, cultural and leisure activities, for example, remained underemphasised. To some extent, and at least in the case of Sweden, this can be explained by the tendency of popular education research to treat popular education separately, rather as part of a larger context-for example the education system as a whole. ${ }^{14}$ In this article, although I

9 "Folk" means "the people", whereas "bildning" is often contrasted to "utbildning", a target in itself rather than a means for obtaining a job, etc. However, the single word "bildning" has much more Humboldtian connotations than the stem in "folkbildning".

10 E.g., the study associations' joint website, http://www.studieforbunden.se/wp-content/files/Folkbildning_engelsk.pdf (accessed February 22, 2014).

11 E.g., Andreas Fejes, Constructing the Adult Learner: A Governmentality Analysis (Linköping: Linköpings universitet, 2006); Swedish Government website, http://www.government.se/sb/ d/6997/a/67943 (accessed February 22, 2014).

12 Folkbildning in Sweden (2007), published at the website of Folkbildningsrådet, http://www.folkbildning.se; search path: index $>$ Folkbildning $>$ Translations $>$ English (accessed February 22, 2014). See also the website of Mimer, the popular education research network at Linköping University, http://www.ibl.liu.se/pedvux/folkbildning?l=en (accessed February 22, 2014).

13 Cf. Benedict Anderson, Imagined Communities: Reflections on the Origin and Spread of Nationalism (London: Verso, 1983); Michael Billig, Banal Nationalism (London: SAGE Publications, 1995).

14 Anna Lundin, Folkbildningsforskning som fält - från framväxt till konsolidering (Linköping: Linköpings universitet, 2008); Fay Lundh Nilsson, "Den svenska folkhögskolans yrkesinriktade utbildningar 1868-1940," in Två sidor av samma mynt? Folkbildning och yrkesutbildning vid de nordiska folkhögskolorna, ed. Fay Lundh Nilsson and Anders Nilsson (Lund: Nordic Academic Press, 2010), 81-82. See also Odd Nordhaug, "Livslang læring: forskningsmessige utfordringer," in Livslang loering: En antologi om voksenoppleringens mangfold og enhet, ed. Vigdis Haugerud and Jørg Kvam (Trondheim: Norsk voksenpedagogisk forskningsinstitutt, 1993). 
will analyse institutions labelled popular education only, my aim is rather the opposite: to show that so-called popular education is not an island.

\section{State subsidies as regulation}

Since popular education is largely organised within the voluntary sector, an analysis of the state subsidies connects to the research field on the non-public, voluntary sector and its relations to the state. In that research, there is a tendency to abandon rigid and binary oppositions between state and civil society. ${ }^{15}$ Thus, I find it fruitful to grasp the state and the non-public sector as a totality to be analysed.

The economics of education research is another obvious setting for the topic of this article. Contrary to the usual points of analysis in that field, which focus on effectiveness, the overall outcome on the human capital and the benefits for society as a whole, I analyse government funding as a regulating mechanism. ${ }^{16}$ To some extent, I study the funding streaming to the popular education organisations, but my main interest lies on the policy level-the conditions for funding. This is important as, in previous research, the importance of state funding of Swedish popular education has often been noted, ${ }^{17}$ but never really studied as the main topic in itself. ${ }^{18}$

Overall, one can speak of a single funding system. The subsidies were instigated and reformed in a political process, with official reports, government bills, parliamentary motions and debates. There, the various conditions of the subsidies and the overall contour of the system were decided and formed. This was often met with conflicting views, particularly visible in the parliamentary material and in consul-

15 E.g., Nancy L. Rosenblum and Robert C. Post, eds., Civil Society and Government (Princeton, N.J.: Princeton University Press, 2002); Lars Trägårdh, ed., State and Civil Society in Northern Europe: The Swedish Model Reconsidered (New York: Berghahn Books, 2007); Stephen P. Osborne, ed., The Third Sector in Europe: Prospects and Challenges (London: Routledge, 2008). For a valid critique of the traditional demarcation between "state" and "(civil) society", see Nikolas Rose, "Governing 'Advanced' Liberal Societies," in Foucault and Political Reason: Liberalism, Neo-Liberalism and Rationalities of Government, ed. Andrew Barry, Thomas Osborne and Nikolas Rose (London: UCL Press, 1996), 37-41.

16 Cf. Eric A. Hanushek, et al., eds., Handbook of The Economics of Education, 4 vols. (Amsterdam: North-Holland/Elsevier, 2006-11); for a somewhat more related study that focuses on the state-private sector dimension regarding the formal school systems, see David Mitch, "School Finance," in International Handbook on the Economics of Education, ed. Geraint Johnes and Jill Johnes (Cheltenham: Edward Elgar, 2004), 260-98.

17 E.g., Bo Andersson, Folkbildning i perspektiv: Studieförbunden 1870-2000 - organisering, etablering och profilering (Stockholm: LTs förlag, 1980), 256-70; Inge Johansson, För folket och genom folket: om idéer och utvecklingslinjer i studieförbundens verksamhet (Stockholm: Liber Utbildningsförlaget, 1985); Lena Lindgren, Kan en filthatt stärka demokratin? Om mål och ideal i folkbildningssammanhang (Stockholm: Carlsson, 1996), 31-40.

18 In another related research field where state funding of the third sector is studied, extant studies tend to focus on economic impacts, but there are also discussions on a general tension between securing the existence of voluntary organisations, and diminishing their autonomy - see Stefan Toepler, "Government Funding Policies," in Handbook of Research on Nonprofit Economics and Management, ed. Bruce A. Seaman and Dennis R. Young (Cheltenham: Edward Elgar, 2010), 322-26. See also Pernilla Jonsson and Silke Neunsinger, Gendered Money: Financial Organization in Women's Movements, 1880-1933 (New York: Berghahn Books, 2012), which also studies the financial aspects of Swedish voluntary associations. However, its focus differs from that of my study, namely on the voluntary organisations themselves and how they raised money. Cf. also Gøsta Esping-Andersen, The Three Worlds of Welfare Capitalism (Cambridge: Polity Press, 1990), 106, who emphasises that the actual construct of state welfare systems in various dimensions must be analysed, rather than simply comparing expenditures; "social-spending levels may camouflage more than they reveal". 
tation bodies' opinions on official reports, that are gathered in the government archives. From 1919 to 1991, the distribution of funds had to be approved by a state authority, the National Board of Schools (Skolöverstyrelsen, hereafter referred to by its abbreviation $S O ̈$ ) that interpreted the parliamentary decisions with its own detailed rules and decisions. In many cases, SÖ worked close to the larger popular education organisations through consultation and delegation of certain decisions on, for example, distribution of subsidies to singular lectures or study circles. In many ways, there was a kind of seamless web between "state" (government, parliament, SÖ) and "civil society" (non-public popular education). This structure was partly a result of many politicians active in popular education issues, as well as many SÖ officials, being rooted in the popular education movement. ${ }^{19}$ The following study builds upon all the aforementioned source categories.

Municipalities and county councils (regional municipal authorities) also provided important contributions to popular education, the latter also owning a large part of the folk high schools. In my research, mostly due to the limitations of the project funding, my focus is restricted to the state subsidies only. Since the aim is to delineate the regulating mechanisms in conditions, rather than measure the amount of funding and its impact, I find that limitation excusable.

The regulating mechanisms of the state subsidy system are of different kinds and are sometimes overlapping. I have chosen to divide them into five regulatory dimensions - whereby the term "dimension" is used to stress that they are different aspects, rather than excluding each other: ${ }^{20}$

- monetary regulation (the regulatory impact of the subsidies themselves)

- organisational regulation (conditions regarding organisations)

- formal regulation (conditions regarding educational practises)

- ideological regulation (conditions regarding politics, religion, morale, etc.)

- demarcating regulation (towards things not considered popular education)

Some brief examples of the first four regulatory dimensions will be given here, in order to provide the full picture of the funding system. ${ }^{21}$ This will enable me to engage more thoroughly in the demarcating regulation, in which "popular education" has been shaped as a specific set of institutions and practices. The period of almost a century that this article focuses on is deliberately long, since the purpose is to demonstrate the main mechanisms of the funding system in itself, rather than analysing the results of specific reforms, for example. Even though some aspects of this process changed during the twentieth century, there was continuity in others.

19 For numerous examples concerning the folk high schools and the state, see Sven Swensson, "Folkhögskolan och myndigheterna," in Svensk folkhögskola 100 år, vol. 1 (Stockholm: Liber, 1968). The ways non-public organisations were included in governance has been described as a typical feature in mid-twentieth century capitalism, see Rolf Torstendahl, Bureaucratisation in Northwestern Europe, 1880-1985: Domination and Governance (London: Routledge, 1991).

20 Thus, the concept is used in a way similar to, e.g., Jörn Rüsen's three dimensions of historical culture; Jörn Rüsen, History: Narration, Interpretation, Orientation (New York: Berghahn Books, 2005).

21 These will be more thoroughly presented in subsequent publications. 


\section{Monetary regulation}

For various popular education institutions, the size and character of the subsidies have often been the very basis of existence. Here, it has often been a question of prioritising between different forms of institutions. As can be seen in Table 1, the three institutions of folk high schools, lectures and study circles together increased their relative share of the total subsidies to education and research in the second half of the twentieth century. This suggests that not only the general growth of the modern welfare state can explain popular education's quantitative progress, but also demonstrates that study circles were most favoured of the three institutions: ${ }^{22}$

Table 1. State subsidies for popular education, 1915-1985

$\begin{array}{rrrrr}\begin{array}{r}\text { Part of the total } \\ \text { subsidies from the } \\ \begin{array}{r}\text { Ministry of Educa- } \\ \text { tion and Research }\end{array}\end{array} & \begin{array}{r}\text { Subsidies } \\ \text { folk high } \\ \text { schools }\end{array} & \begin{array}{r}\text { Subsidies for } \\ \text { lectures/ cultu- } \\ \text { ral programs }\end{array} & \begin{array}{r}\text { Subsidies } \\ \text { for study } \\ \text { circles }\end{array} & \begin{array}{r}\text { Average } \\ \text { subsidy to } \\ \text { each study } \\ \text { circle }\end{array} \\ \begin{array}{r}\text { MSEK } \\ \text { (1914 value) }\end{array} & \begin{array}{r}\text { MSEK } \\ \text { (1914 value) }\end{array} & \begin{array}{r}\text { MSEK } \\ \text { (1914 value) }\end{array} & \begin{array}{r}\text { SEK } \\ (1914 \text { value) }\end{array} \\ 0,56 & 0,29 & 0,23 & - & - \\ 0,87 & 0,52 & 0,16 & - & - \\ 0,77 & 0,69 & 0,10 & - & - \\ 1,24 & 0,99 & 0,03 & - & - \\ 1,72 & 2,50 & 0,11 & 1,03 & 21,41 \\ 3,99 & 6,96 & 0,36 & 4,42 & 38,52 \\ 3,29 & 16,95 & 0,61 & 30,56 & 109,73 \\ & 19,40 & 4,38 & 31,39 & 107,15\end{array}$

The level of state funding is only part of the story, another is the character of the government subsidies. During most of the studied period, there have been three major types of subsidies, one of which was simply called "subsidies". From these undesignated subsidies (obetecknade anslag), only the allocated sum could be used, and only during the year in question. In contrast, when a reservable subsidy (reservationsanslag) was granted, unused funds could be saved and used in the next budget period. In the most favourable form, the propositional subsidy (förslagsanslag), the allocated sum was more a form of checkpoint that could be exceeded. It is easy to understand that the propositional subsidies were generally regarded as advantageous, while the other two types often resulted in a selection of the intended recipients. During the period studied here, in Swedish popular education, all subsidies to folk high schools, study circles and libraries were propositional, whereas the lectures had the lower

22 The allocated subsidies are to be found in Statsliggaren, a yearly publication listing the government's subsidies with details on "sub-subsidies", e.g., the study circle and lecture subsidies have at certain periods been parts of a certain subsidy. Regarding the folk high schools, some additional subsidies are included at certain dates: "increased subsidies" and grants for construction work; however, grants to student fees are not included. The numbers of study circles are from Statistisk årsbok, the annual report från SCB, the state statistics authority. For calculating the price value of 1914, tables of Consumer Price Indices were taken from Konsumentprisindex 1830-2001 at SCB's website, http:// www.scb.se/statistik/PR/PR0101/2000I02/PR15SM0201.pdf (accessed February 22, 2014). 
grades. As can be seen in Table 1, the lectures were also treated more harshly in bad economic periods before and during World War II. ${ }^{23}$

The regulations determining the proportion of the popular education activity that the state would fund are another important factor. A general demand of matching funds meant that the state met only a part of the total costs of the institutions, while the rest had to be compensated from municipal or private grants and donations. Also in this respect the study circles had - at least until 1981 — very advantageous conditions with up to 75 per cent of the costs covered by the state. ${ }^{24}$

\section{Organisational regulation}

The state subsidy system has to a large extent shaped the organisational structures of popular education. From the beginning, for example, a basic demand that recipients should have a board was in place. ${ }^{25}$ In some instances, functions-such as study directors, formal leadership and the like-were also mandated.

Perhaps the most important feature imposed by the state subsidy system is the creation of the study associations (studieförbund) that has primarily organised study circles. They were largely formed due to the condition for state funding introduced in the 1912 library reform, when libraries bound to study circles were given subsidies. This requirement was motivated by a wish for efficiency and means of control from the state. Official investigator Valfrid Palmgren proposed that they should have at least 20000 members throughout the country. Although the leading temperance organisation, the Good Templars, already met that requirement, it was soon followed by the new study organisation of the workers movement-ABF-that quickly became the largest study association which it still is. ${ }^{26}$ The exact minimum rules have changed, but not the general outline, and a number of additional study organisations were formed over time. From the 1920s, there has also been a regular subsidy for the organisational and administrative costs of the study associations. ${ }^{27}$ Thereby, the state had formed large bureaucratic organisations that gradually started to take part in the distribution of state subsidies to single libraries and study circles.

\section{Formal regulation of educational practices}

The state subsidy system has also formed the educational practices. For example, from the outset, the public lectures were to be held regularly, which was later followed by rules that mandated a fixed minimum number of lectures per year. Regarding the folk high schools, the state regulations became rather precise in 1919, including a number of rules concerning obligatory teaching subjects and the minimum numbers of lesson hours per week, among other stipulations. ${ }^{28}$

23 It should be noted that, 1974, the lecture subsidies were subsumed into "cultural programs", with a direct increase in c. 150 per cent, and once again in 1981 with an approx. 250 per cent rise of the allocated money.

24 E.g., SFS 1965:170, 8 \$.

25 See Anne Berg's article in this issue.

26 Valfrid Palmgren, Förslag angående de åtgärder, som från statens sida böra vidtagas för främjande af det allmänna biblioteksväsendet $i$ Sverige, afgifvet den 28 september 1911 (Stockholm: Ivar Hæggströms boktryckeri, 1911), 172-77; cf. Jonas Åkerstedt, Den litterate arbetaren: Bildningssyn och studieverksamhet i ABF 1912-1930 (Uppsala: Uppsala universitet, 1967), 53-54.

27 Rskr. 1921:310.

28 SFS 1913:397; SFS 1919:866. 
With respect to the study circles, they were largely defined by the state subsidy system. Before 1947, when the circles received funding indirectly via libraries, they lacked formal definition. However, in the 1947 legislation, a study circle was defined as "a ring of comrades [kamratkrets] for common theoretical or practical studies over a specified subject following a pre-arranged plan". This description was slightly changed in 1963 into "a ring of comrades for common studies according to plan, over a pre-specified subject or problem area". ${ }^{29}$ While the definition was rather open, the quantitative rules on practices were more precise. Apart for strict rules concerning number, regularity and length of single meetings, the size of circles was mandated to include five to twenty members, with some possibilities for exception. Concerning age, study circle members were stipulated to be at least 14 years old - in the period 1947-63 there was even a specific category called "youth circles". From 1953, however, music study circles were allowed to have up to half the members younger than 14 years old. ${ }^{30}$

\section{Ideological regulation}

The ideological implications of the popular education subsidies can be broadly described as a development from explicit to implicit norms on politics and morale. On the other hand, the ideas concerning popular education's overall meaning for society have shifted. From the start, the public lectures were conditioned to be free from "political and religious battles or negotiations", which was later made milder, making at least possible to discuss political issues. Before 1963, the study circles were also forbidden to include "propaganda for political or religious views". ${ }^{31}$

Later in the twentieth century, two other ideological conditions of a rather vague character became dominant, the first being a sort of democratic ideology stressing values of objectivity. In the 1963 popular education reform, study circles and public lectures were expected to perform so that an "objective and comprehensive illumination of the study subjects" was realised. Furthermore, the work should be "conducted in a spirit of tolerance and respect for diverse opinions" and in such a way that promoted "independent thinking and stances". ${ }^{2}$

Secondly, there was a marked tendency to promote educational and/or cultural quality in the activities. In the late nineteenth and early twentieth century, a sharp line against what was considered immoral in the rules for state subsidies was evident. Thus, until 1930, libraries were prohibited from including "books with indecent content". While the rules gradually became milder, until 1965, a library had to follow regulations from SÖ. Thus, if the latter found the book stock not to be in a "generally satisfactory condition from a moral or artistic point" penalties could follow. It further stipulated that "young and immature readers" should not have access to literature "of a nature that they might be harmful in moral respect". ${ }^{33}$

The trend that emerged in the 1960s - whereby vocational and formal adult education within study associations and folk high schools was promoted-was also part

29 SOU 1946:68, 167, 251; SFS 1947:508, 22 \$; prop. 1963:36, 59-60; SFS 1963:463, 7 \&; SFS 1981:518, $11 \S$.

30 SFS 1947:508, 24 \, 26 \$ b; SFS 1953:392, 24 §; SFS 1963:463, 8-9 \$\$.

31 SFS 1884: bih. 34; SFS 1929:239, 3 \$ i; SFS 1947:508, 4 \$ i, $26 \$$ f.

32 SFS 1963:463, 2 \$.

33 SFS 1905:29; SFS 1930:15, 4 \$ h; SFS 1955:540, 3 \$f. 
of an ideology. This is in line with the "lifelong learning" ideology prominent from the late twentieth century into our time, promoting popular education for "flexible capitalism", ${ }^{34}$ overriding the regulations in the 1970s that cultural programs, for example, must not have any commercial connection. ${ }^{35}$

\section{Demarcating regulation - defining popular education}

The very concept of "popular education" has long been a political issue. Since 1991, there has been a unified government subsidy for "popular education" (folkbildning), which is to be shared by folk high schools and study associations - the latter for study circles and cultural programmes under their roof. Prior to this change, subsidies were generally specified for particular activities and organisations. Still, from the late nineteenth century onwards, there has been a discourse on "popular education" with at least a core meaning, where folk high schools, public lectures, libraries and study circles were included..$^{36}$ From the start, popular education had a very positive connotation. Socialists, liberals and even conservatives regarded it as bringing promises for the future. In the official report of the 1920 popular education committee, "free and voluntary popular education" was defined as open for everyone regardless of class and educational background. It was different from schools and aimed at grown-ups, with the purpose of nurturing civic virtues and spiritual values. ${ }^{37}$

In the early twentieth century, the term itself entered into the names of societies that supplied books and lectures (e.g. Folkbildningsförbundet in 1903), often connected to university extension. The latter is interesting as, well into the 1920s, many leading figures in popular education, such as Oscar Olsson and Carl Cederblad, regarded the universities as a natural centre of popular education, often citing England as an example. Public libraries-including those organised by cities and municipalities - were also considered the very foundation of popular education..$^{38}$ That is indeed different to the marked association between popular education and popular (social) movements in the voluntary sector, which has been more pronounced in late twentieth century official discourse. ${ }^{39}$ Today, libraries are only occasionally described as popular education institutions, presumably since, from the 1960s, they have been almost exclusively organised by the municipalities.

From 1914 onwards, libraries, lectures and a number of other purposes, such as university extension and temperance education, were listed in the government budgets under the category "Other popular education measures" (Folkbildningsåtgärder $i$ övrigt). That category existed until 1960/61, and included the study circles from 1947. In contrast, the folk high schools were instead connected to primary schools in the government budgets. However, in other official contexts, such as the organisation of SÖ, the folk high schools were clearly linked to "popular education". ${ }^{40}$

34 Ann-Louise Petersen, Marknadsorientering inom folkbildningen: Fritt och frivilligt i ett nytt ljus (Göteborg: Bokförlaget BAS, 2006); Andreas Fejes and Katherine Nicoll, Foucault and Lifelong Learning: Governing the Subject (London and New York: Routledge, 2008).

35 SFS 1974:454, $3 \$ 2$ mom.

36 E.g., Reformatorn no. 12, 1887.

37 SOU 1924:5, 9.

38 SOU 1924:5, 9; Ingvar Törnqvist, Oscar Olsson folkbildaren: I synnerhet hans tankar om universitetens roll i folkbildningsarbetet (Stockholm: Sober, 1996).

39 E.g., SFS 1981:518, 7 §.

40 SFS 1919:812, 2 \$ (“anordningar för idrott och allmän fysisk utbildning”); SFS 1943:962, 2 \$. 


\section{Early demarcation issues}

Still, from the beginning there were no fixed boundaries separating popular education from other areas. For example, there were many cases where "popular education" institutions purposely transcended into areas of moral training and leisure activities. Indeed, the subsidies for public lectures had the condition of "popular education purpose" (folkbildningssyfte) removed in 1911, since a previous committee report explained that, in remote areas, it would be sufficient to demonstrate that the institutions contributed by providing individuals with a better way of spending leisure time. ${ }^{41}$ In the early twentieth century, the morally uplifting aspect of popular education was particularly emphasised. This was not only a politically conservative reaction against a dangerous working class youth, it was generally shared by those Liberals and Socialists who made up the majority within most popular education institutions. ${ }^{42}$ The aforementioned 1920 committee was to some extent instigated by a general fear of the youth forming bad habits, ${ }^{43}$ and it stressed a better entertainment as one of the positive effects of lectures or study circles. ${ }^{44}$

Moreover, the 1911 lecture reform opened up the possibility for compensatory adult education or even vocational training. In places where "elementary practical courses for adults" were not available, one third of the subsidies for public lectures could be used for courses in Swedish, arithmetic, childcare, etc. ${ }^{45}$ Some agents commenting on the preceding official report believed that these objects warranted a subsidy on their own ${ }^{46}$ while others regarded them as a effective means of luring workers into the core fields of popular education. ${ }^{47}$ However, only a small number of lecture organisations used this opportunity. This resulted in the introduction of a new subsidy in 1928 for so-called itinerant folk high schools (a hybrid between folk high schools and lectures)..$^{48}$

In reality, much of the popular education functioned as "citizen education" (medborgarbildning) with the purpose of being a replacement for the regular school. ${ }^{49}$ That is also true for the folk high schools, which were largely responsible for formally distributing formal vocational training for the agricultural youth. ${ }^{50}$

41 Förslag angående ändrade grunder för statsunderstöd åt anstalter för populärvetenskapliga föreläsningar avgifvet den 12 januari 1911 af tillkallade sakkunniga (Stockholm: Ivar Hæggströms boktryckeri, 1911), 45-46.

42 Samuel Edquist, Nyktra svenskar: Godtemplarrörelsen och den nationella identiteten 1879-1918 (Uppsala: Uppsala universitet, 2001); Per Sundgren, Kulturen och arbetarrörelsen: Kulturpolitiska strävanden från August Palm till Tage Erlander (Stockholm: Carlsson, 2007).

43 E.g., AK mot. 1919:299 (Albert Zander); FK mot. 1920:179 (Oscar Olsson), 13-14.

44 E.g., SOU 1924:5, 78, 119. "Lifting of the entertainment culture" was a topic that the committee announced would have been examined if it had not been ended too abruptly: SOU 1924:5, 8.

45 SFS 1911:bih. 40, 8.

46 Prop. 1911:216, 25-26; opinions from länsstyrelsen $i$ Göteborgs och Bohus län and Lundby arbetareinstitut (no. 14) in: Ecklesiastikdepartementets arkiv (huvudarkivet), konseljakt 1911-04-21 no. 80 , 1 st of 3 vols. [Riksarkivet Marieberg].

47 Opinion from länsstyrelsen i Malmöhus län (no. 12) in: Ecklesiastikdepartementets arkiv (huvudarkivet), konseljakt 1911-04-21 no. 80, 1st of 3 vols. [Riksarkivet Marieberg].

48 SOU 1924:5, 92, 132 f.; SFS 1928:418, 2 \ mom 1 a. Cf. also SÖ’s opinion (page 63) on SOU 1924:5, in: Skolöverstyrelsens arkiv, 05 Folkskoleavdelningen, B I a, vol. 83 [Riksarkivet Arninge].

49 Cf. Bernt Gustavsson, Bildningens väg: Tre bildningsideal i svensk arbetarrörelse 1880-1930 (Stockholm: Wahlström \& Widstrand, 1991).

50 Lundh Nilsson (2010). 


\section{Demarcation questions in the era of mass popular education}

In 1947, study circles started to be directly funded by state subsidies, and soon became the by far greatest institution of Swedish popular education, organised within study associations. As we shall see, this quantitative rise soon created a strengthened need to underpin the borders between "true" popular education and other spheres, with the study circles as the main example.

Soon, the borders towards leisure and "hobby" activities_for adults and young people alike-were in the foreground of the discussion, and have been present ever since. In the 1960s, formal adult education rose to the foreground, and with that discussions on its borders with "true" popular education.

In the 1970s and 1980s, another demarcation area came to the forefront, namely that towards cultural activities, fuelled by the stronger political involvement in that area. Typically, demarcation issues were in the focus of the political treatment of popular education. For example, the committee that issued an official report in 1979, which eventually led to the 1981 popular education reform, had an entire chapter on demarcation issues, pertaining specifically to municipal adult education, higher education and corporate education.

The story is rather paradoxical though. Demarcation aspirations have gone hand in hand with popular education institutions being actively used by public authorities for means not traditionally considered be a part of the core public education. That development has led to a strengthened divergence between ideal and organisational popular education.

\section{Blacklisting hobby circles and others}

Soon after the introduction of the study circle subsidies in 1947, it was clear that they were a popular activity. Hundreds of thousands of Swedes flocked to the study circles, making them one of the more common spare time activities in a country where the standard of living increased rapidly after the war.

Consequently, the funding the state dedicated to these activities increased very quickly. However, after only a few years, the government and parliament decided to impose limitations. Alongside a new maximum limit of funding a single study circle could receive each year, it was legislated in 1952 that subjects that were deemed having a "hobby" character-as determined by SÖ, after consulting the study associations - would not be funded. The resulting list was very short-three subject areas were forbidden, namely "sports (e.g., table tennis, gymnastics, orienteering)", "board games (e.g., bridge, chess)" and "parlour games (e.g., ballroom dancing, folk dance, folk games)". ${ }^{51}$ At the same time, study associations were ordered to be careful when approving study circles that were of a practical nature, so that they had to perform "qualified studies". In 1956, these stipulations were further sharpened, obliging all study circles in visual arts, handicraft, music, handiwork (slöjd) and theatre to be approved by specially assigned specialists within the study associations, to ensure quality. ${ }^{52}$

Two years later, in 1958, after consultations between the study associations and

51 SFS 1952:602, $26 \$$ i; Undervisningsavdelningens protokoll 1952-08-26, 2 \$, in: Skolöverstyrelsens arkiv, 08 Undervisningsavdelningen, A I a, vol. 1 [Riksarkivet Arninge].

52 SFS 1956:251, $26 §$ h; Undervisningsavdelningens protokoll 1956-07-17, 3 \$, in: Skolöverstyrelsens arkiv, 08 Undervisningsavdelningen, A I a, vol. 15 [Riksarkivet Arninge]. 
SÖ, the latter issued an even more detailed list of subjects that were outright forbidden (the list of 1952 was now extended to include, for example, "charm courses" and "basket weaving") or had to be carefully controlled in advance, such as, for example, "lace making" and "TV building". ${ }^{3}$

However, these lists were removed in the 1963 popular education reform, which signalled a more positive view of practical education, describing it as having the same value as theoretical education. It was emphasised that having lists of subjects was not the proper way of deciding the border between popular education and other activities. Instead, the decision should be based on the purpose of the studies, and the conditions concerning leaders and study materials. ${ }^{54}$ These decisions were supposed to be continuously discussed by SÖ in consultation with the study associations-something that was, in the following years, conducted in the so-called Pedagogical Board composed of members of the study associations. There, mainly study materials for practicing study circles were discussed. ${ }^{55}$

Ironically, in 1968, a new list of forbidden subjects and subject areas was issued by SÖ, created by the so-called Demarcation Board of the Popular Education Bureau (FGN, Folkbildningsbyråns gränsdragningsnämnd), founded in 1967. While many of its members were from the study associations, it was still formally a part of SÖ. The FGN was supposed to discuss all border issues between popular education and other fields. For example, it was responsible for examining study materials for subject areas in the risk zone. ${ }^{56}$ The 1968 list was changed and renewed a number of times until 1991, when the system was terminated. The outcome was excluding subjects or including new ones, such as "lampshade manufacture" in 1982, or "flower arrangement" in 1989. The archived discussion protocols make it possible to follow the lines of argument:

The members' common understanding was that this is a material that should not be used. The subject may in many ways be compared with the tabletop, rockery planting etc. One has to be skeptical about the subject, otherwise it will be necessary to approve other questionable ones.

From SÖ's side it was pointed out, that even if flower arrangement is popular, it belongs to such a flair that may be without state subsidies when society does not have the money for health care, school meals and such. Accepting this would not benefit the reputation of popular education and the outside view of study circle activities.

[...]

FGN decided with a clear majority to recommend the rejection of the subject of flower arrangement. The justification is that the material does not meet the purpose and content requirements FGN places on a study material. ${ }^{57}$

53 ASÖ 1958:17, pt 83, pages 266-68.

54 Prop. 1963:36, 12-13, 62.

55 Bidragsvillkor och avgränsningsfrågor i studiecirkelverksamheten: Promemoria upprättad inom Utbildningsdepartementet (Stockholm, 1970), 6-7; protocols from Pedagogiska nämnden, in: Folkbildningsförbundet med föregångares arkiv, 03 Samverkande Bildningsförbunden, F3B, vol. 1 [Riksarkivet Arninge].

56 Bidragsvillkor (1970), bilaga 1.

57 SÖ-FS 1982:173; SÖ-FS 1989:71, p. 2.2 i.; FGN minnesanteckningar 1988-10-06, page 4, in: Skolöverstyrelsens arkiv, $83 \mathrm{~V}$-avdelningen, 03 Enheten för studieförbund, F1A, vol. 1 [Riksarkivet Arninge]. See also Per Hartman, Att bilda med bild: En studie av de praktisk-estetiska studiecirklarnas utveckling (Linköping: Linköpings universitet, 2003), 189-96. 
In official documents - such as official reports, government bills and the regulations from SÖ-there was a continuous ambivalence between stressing the difficulties of demarcation and that it should rather focus on purposes in singular cases on one hand, and the general banning of whole subjects on the other. ${ }^{58}$ Previous research also indicates that practical studies failed to achieve the highest prestige and support within popular education organisations. ${ }^{59}$

In parliament, the right-wing Moderate Party in particular had a rather "economical" attitude towards popular education, especially concerning aesthetical study circles. In some parliamentary motions, the attitude towards these forms of education was rather sharp. Sometimes, it was put in question whether they had any value at all for society:

\begin{abstract}
We are, however, very reluctant concerning the fact that state and municipalities like now should finance socialising and recreation. One might think that it is useful to learn how to sew certain clothes. But there are examples of people who have attended a dressmaking circle for 16 years. People weave in the same circle year after year, gathering precious tissues that they made virtually no cost at all. Washers and ships made of dead matches are in the thousands. If you think this is fun, you should of course go on with it, preferably in a group, but the question is whether it must be supported by tax money. ${ }^{60}$
\end{abstract}

\title{
After-school activities for youth and popular education
}

The demarcation towards "hobby" subjects is related to another one that rose to prominence in the 1950s. Starting in 1954, state subsidies were issued for after-school activities for youth, in leisure groups (fritidsgrupper) arranged by study associations or municipalities. ${ }^{61}$ The question of the youth's leisure activities had been a central issue for a long time. As we have seen, popular education was often regarded a suitable way of integrating young people into society, offering them activities of good value. Long before 1954, state subsidies were offered to the youth organisations within the temperance movement and, from 1941, there were also specific state subsidies for settlements (hemgårdar). These targets were associated to the popular education sphere, and the new funding of after-school activities was also connected to popular education, for example within the government budget until 1977, as well as in the organisation of SÖ.

In preparing the 1954 reform, the boundaries between study circles-already open for anyone 14 years old or older - and after-school activities were discussed, in ways similar to those concerning education vs. "hobby" activities. Nonetheless, the demarcation remained unclear; a 1960 committee was obliged to discuss both "po-

58 Bidragsvillkor (1970), bilaga 1 (the 1968 list), pt 5.1; SOU 1979:85, 195-96; Studieförbunden inför 90-talet: En analys av studieförbundens situation, verksamhet och uppgifter (Stockholm: Skolöverstyrelsen, 1988), 54-55.

59 Gull-Mari Rosén, Konst- och konsthantverkscirklar under 1970-talet: De fyra största studieförbundens syn på denna verksamhet med anledning av den nya kulturpolitiken (Umeå: Umeå universitet, 1984); Hartman (2003).

60 Mot. 1980/81:1301 by Blenda Littmarck and Anita Bråkenhielm.

61 SFS 1954:575, 11-14\$\$. 
pular education" and "youth activities", as well as the boundaries between them. ${ }^{62}$ In the 1968 FGN list on the boundaries of study circles, once again, it was emphasised that "the borders between study circle and leisure group activities are maintained." 63

\section{Vocational education and formal adult education}

In the 1950s and 1960s, popular education was also frequently discussed in relation to vocational education, raising issues similar to those concerning youth and hobby activities. The 1958 list also included a regulation that study circles aiming at basic vocational training must not be arranged in places where such education was already or could be fulfilled by existing vocational schools (yrkesskolor) ${ }^{64}$ Further, it was stipulated that, in each case, vocational training should also be approved by the study associations and SÖ.

Thus, there was a pragmatic solution, similar to those of 1911 and 1928, discussed above. In the early 1960s, according to the results of an investigation, around 4 per cent of all study circles pertained to vocational education. At the time, border issues were evident; both study associations and vocational schools claimed that the other stepped into its territory. ${ }^{65}$

In the late 1960s, the demarcation between study circles and vocational education was integrated into a larger field - that between popular education and formal adult education as a whole. The 1960 s were marked by major reforms in the Swedish educational system - not least with new primary and secondary school systems. The overall development resulted in the view that more Swedes should go to school for a longer time. In this process, the compensatory adult education was reformed, so that grown-ups could be given opportunity to attend primary and secondary school level courses. Owing to a parliamentary decision in 1967, municipal schools for adults (Komvux) developed rapidly from 1968 onwards.

Before this reform, popular education institutions, such as folk high schools and "evening gymnasia" (kvällsgymnasier) organised by some study associations, had in practice performed functions of formal compensatory education for adults. ${ }^{66}$ Folk high schools also functioned in some instances as formal steps on the educational ladders, making it possible to gain entry to formal schools. As a result, in 1957, folk high schools were allowed to issue a form of grades. ${ }^{67}$

With the 1967 reform, the activities in study circles and folk high schools were formally included in the wider concept of "adult education" (vuxenutbildning), both within government budgets and in SÖ's internal organisation. On one hand, study

62 Bidrag till ungdomens föreningsliv och fritidsverksamhet: Betänkande med förslag av 1953 års utredning angående stöd åt nykterhetsorganisationer och ungdomsvårdande sammanslutningar, II (Stockholm, 1953), 58-60; SOU 1961:44, 10, 11, 190.

63 ASÖ 1970/71:15, 8 .

64 ASÖ 1958:17, pt 83, page 267.

65 SOU 1966:3, 581-84; prop. 1967:85, 73-74.

66 Andreas Fejes, "Kvällsgymnasier - resultatet av ett vägval i vuxenutbildningens historia," Vägval $i$ skolans historia 3, no. 4 (2003); cf. Staffan Larsson, "Förnyelse som tradition," in Folkbildning - samtidig eller tidlös? Om innebörder över tid, ed. Ann-Marie Laginder and Inger Landström (Linköping: Linköpings universitet, 2005), 182-83.

67 Prop. 1957:146; SU bet. 1957:173; Swensson (1968), 265; Per Hartman, Skola för ande och hand: En studie av folkhögskolans praktisk-estetiska verksamhet (Linköping: Linköpings universitet, 1993), $137,143,190-91$. 
circles and folk high schools were defined as something other than formal adult education institutions with grades and exams. This was underlined in the government bill of 1967, which emphasised that study circles and folk high schools played important roles in adult education, but that one had to clear the line not least concerning vocational education. ${ }^{68}$ At the same time, a working group was instigated within SÖ, to examine and decide on the border between popular education and formal adult education at the secondary school level. The government ordinance issued in 1967 approved that municipal vocational school courses could be arranged as study circles. The exact rules were formulated by SÖ, defining subjects that would be organised by municipal vocational schools or by study associations as study circles. ${ }^{69}$

On the other hand, there was an increasing demand that folk high schools and study circles should actively engage in and be used for compensatory education and certain forms of vocational training. ${ }^{70}$ In the 1970s, for example, folk high schools received formal state support in arranging the training of youth workers (fritidsledare). In the government bill, this involvement was justified with the argument that folk high schools for long had had elements of vocational training. Moreover, it was noted that the previous try-outs were successful and that youth work had close connections to popular education. ${ }^{71}$

In the 1970 government bill on adult education, it was emphasised that study circles, due to their informal nature, were ideal in reaching a wide range of socioeconomic groups, elderly people with insufficient formal education in particular. It was also noted that, since the reform of 1967, the young and well-educated seemed to have become overrepresented in adult education as a whole. ${ }^{72}$ Therefore, the subsidies were generally increased, but so-called additional subsidies (tilläggsbidrag) were also introduced for study circles for a well-defined number of purposes. In these so-called high-priority study circles (priocirklar), one could study Swedish, English, Mathematics or Civics corresponding to the primary school syllabus. The additional subsidies were also given for circles aiming at aiding disabled persons in communicating. ${ }^{73}$

The reform was successful; in the third year, 1972/73, almost 80000 high-priority study circles were operational, engaging 716000 participants, equivalent of 36 per

68 Prop. 1967:85, 91-93.

69 SFS 1967:452, 3 \$, 57 \$; ASÖ 1967/68:54, 1-16; ASÖ 1967/68:64, 1-2; cf. Inge Johansson, Striden om vuxenutbildningen 1967-1970: En folkbildares försvarstal (Stockholm: ABF, 1990).

70 A similar development was visible in Norway; Sigvart Tøsse claims that there was a shift in the 1960s whereby adult education was dominantly seen as tool for "formal education, vocational training and labour market policy", and the previous dominant element—culture-turned into the background; however, the latter was revived in the 1970s: Sigvart Tøsse, "Adult Education Trends and Reforms," in Reforms and Policy: Adult Education Research in Nordic Countries (Trondheim: Tapir Academic Press, 2000), 7, 10-11.

71 Prop. 1975:14; SFS 1975:399. Another example is the education of interpreters (kontakttolkar) in study circles and folk high schools, that were formally regulated in 1977 after three years of try-outs: prop. 1976/77:100, 445-56; UbU bet. 1976/77:19, 12; SFS 1977:461. Cf. Inger Landström, Mellan samtid och tradition: Folkhögskolans identitet $i$ kursutbudets yrkesinriktning (Linköping: Linköpings universitet, 2004).

72 Prop. 1970:35, 15, 41, 44-47. Cf. Berndt Johansson, Government-Subsidized Adult Education in Sweden (Stockholm: Swedish Institute, 1973), 26; Lars-Erik Olofsson and Kjell Rubenson, 1970-talets vuxenutbildningsreformer: Reflexioner kring strategier och utfall (Stockholm: Institutionen för pedagogik, Högskolan för lärarutbildning i Stockholm, 1986).

73 SFS 1970:329, 8 §; tilläggsbidrag. 
cent of the total number of study circle attendants. ${ }^{74}$ As the system of additional subsidies was further developed, in 1975, education for immigrants in their native languages, as well as trade union education, was added to the list of additional subsidies. ${ }^{75}$ The system was eventually terminated in 1991, prior to which some changes were introduced-most notably a general cutback in the 1981 reform. The original structure was, however, partially restored in the years following the Social Democrat election victory in $1982 .^{76}$

The 1979 official report on popular education concluded that the "demarcation problems" between study associations and municipal adult education had diminished over the 1970s, but that there would still be concrete demarcation cases in the future. The report advocated that the municipal school boards should arrange consultations on planning that involved all actors in adult education. Moreover, it recommended that the various targets and particularities of different actors be wellknown at least within the organisations and its co-workers. Such statements indicate that the distinction between local practices of study circles and municipal schools for adults was even more difficult. ${ }^{77}$

Another demarcation issue that was often discussed in the 1970s and 1980s was that between popular education and higher education. As previously noted, many of the early popular education initiatives came from the universities. Thus, a (downsized) result of some of the ideas of the universities being the centre for popular education was the state support of so-called university circles from 1924 onwards, with the English tutorial classes as a model. With the 1947 study circle reform, university circles were defined as a distinct form of study circle with high demands with respect to leader qualifications and quality of educational content. ${ }^{78}$ The 1979 official report, however, found it necessary to uphold the demarcation between popular education and higher education, since the latter recently received broader assignments. The outcome was that university circles that followed a syllabus were no longer eligible for receiving state support, since they did not accord with "the work form and purpose of the study circle".79 As this issue became a political battlefield, the proposal was not realised until after the Social Democrat election victory in 1982. In the following years, Moderate and Liberal representatives repeatedly demanded that syllabus-bounded university circles should once again receive subsidies. ${ }^{80}$

74 SOU 1974:54, 90.

75 SFS 1975:428, 9 §.

76 SFS 1981:518, 19 and 24 \$S; cf. SFS 1984:569, 19 and 24 \$\$. In 1987 and 1988, additional subsidies were also introduced for those that were not sufficiently educated, combined with freer rules on the length of meetings and such; SFS 1987:536, 21a \$; SFS 1988:583, $26 \mathrm{~b} \$$.

77 SOU 1979:85, 81-82. Another indication is the blunt formulation in the 1968 supplementary directions for study circles; "any tendency by various means to denote pure hobby activities and different kinds of sport and recreational activities as education in the spirit of the popular education ordinance, must be curbed" (Bidragsvillkor (1970), bilaga 1, page 2). See also SÖ-FS 1981:138, 16, that emphasised that a certain group could not be funded as a "study circle" and "cultural activity" at the same time.

78 SOU 1924:5, 149-60, 187-89; FK mot. 1924:72; AK mot. 1924:115; rskr. 1924:8 A, 118-21; SFS 1947:508, $24 \S$.

79 SOU 1979:85, 161, 169.

80 Prop. 1980/81:127; prop. 1982/83:100, bilaga 7, 576-78; mot. 1982/83:1913; mot. 1982/83:1915; mot. 1989/90:Ub254; mot. 1989/90:Ub267; mot. 1989/90:Ub825. However, there was also a motion from individual Social Democrats who wanted to reinstitute them in order to strengthen remote regions (mot.1985/86:Ub404). 


\section{Cultural activities and popular education}

From the beginning, cultural activities have been an important part of the programs study circles and folk high schools offered. Once World War II ended, this development became especially prominent, despite the mentioned demarcations against "hobby" and "leisure" activities. At that time, many folk high schools developed a specific aesthetic profile, while study circles offered many subjects in cultural areas. ${ }^{81}$ For example, many prominent pop and rock bands started as study circles. ${ }^{82}$

Over time, it became necessary to formulate demarcations between popular education and (other) cultural activities, owing to the rise of cultural politics as a prominent sphere. In a number of reforms implemented in 1974 and the following years, the subsidies to a number of cultural activities, such as theatres and films, were substantially increased. The reforms emphasised values, such as decentralisation, anti-elitism, and anti-commercialism. In this so called "cultural policy of 1974", popular education was also discussed, and various actors raised the possibility of establishing relations between popular education and the cultural field as a whole. Many actors were critical towards the official report, as it had divided popular education into a "cultural" and "educational" part. ${ }^{83}$

The reform also affected the popular education funding system. Most importantly, the 90-year-old subsidy to public lectures was replaced by a new subsidy for so called cultural programs, which was to include public lectures but also song, music, dance, drama performances, film screenings and exhibitions. The Swedish Arts Council, a new state authority, supervised the programs. Thus, between 1974 and 1991, certain activities in popular education institutions were attached to the state cultural bureaucracy, rather than the educational bureaucracy.

The cultural programs were in themselves a sort of border zone between education and (other forms of) culture. There were no pedagogical or educational demands in the regulations; rather, the new subsidy was-owing to its foundation in the existing study associations that received the largest proportion of the fundingseen as a convenient way of supporting cultural activities. ${ }^{84}$

The official report on popular education of 1979 proposed a widening of the cultural programs subsidies to include means for study circles that wanted to present their results through, for example, films or exhibitions. Their proposed name "other educational activities" was changed in the government bill in 1981 into "cultural activities within popular education, etc.", since the aim was to also include ensemble activities, such as dance or theatre. ${ }^{85}$

The cultural programs brought border issues to the fore, which took two distinct directions - towards study circles and towards cultural activities outside the popular education realm. SÖ stipulated the border towards study circles as a question of the

81 E.g., approx. 30-35 per cent of all study circles in the 1960s: SOU 1972:66, 51.

82 http://www.studieforbunden.se/studieforbund/kultur/musik (accessed February 22, 2014).

83 ABF och Kulturrådets förslag Ny kulturpolitik (Stockholm: Arbetarnas Bildningsförbund, 1973), 5-6, 13-14; see also SÖ, opinion [no. I:20] on SOU 1972:66, page 9-10, in: Utbildningsdepartementets arkiv (huvudarkivet 1975-), konseljakt 1975-02-27 no. 3, vol. marked "del 1 p. 11.3" [Riksarkivet Arninge]. The development of Swedish cultural policy is analysed in My Klockar Linder, Kulturpolitik: Formeringen av en modern kategori (Uppsala: Uppsala universitet, 2014).

84 Prop. 1974:28, 315-17; SFS 1974:454, 3 \$.

85 SOU 1979:85, 263; prop. 1980/81:127, 26-27, 33-40; SFS 1981:519. 
"main target" of the activity in question. For example, in 1981, groups wishing to engage in the subject areas of choirs, ensembles, dance and theatre had to know that study circle subsidies could be obtained if the main target of the activity was to "on the grounds of study circle methods broaden the participants' knowledge and general orientation in the respective subject". On the other hand, if the activity "aims to prepare for public recitals or otherwise don't work according to the principles outlined above", the group had to apply for the cultural activities subsidies. ${ }^{86}$ However, the borders could change; in the 1981 study circle reform, the government explicitly stated that some study circles in the aesthetical area should be completely transferred to cultural activities. One consequence of this change was the banning of study circles in dance, including folk and jazz dance, from July 1982 onwards. However, later in the 1980 s, dance was once again allowed as a study circle subject area. ${ }^{87}$

Thus, in the late twentieth century Sweden, the study associations have functioned as an important actor in the cultural field as a whole. That situation has also created some conflicts between the popular education sphere and independent cultural actors, such as local theatre groups and the like. The main objection of the latter was that the study association bureaucracy intervened into the cultural field, getting its "own" state subsidy earmarked for cultural activities in popular education organisations. Moreover, the independent actors felt that state subsidies for local cultural activities should, to a lesser degree, be allocated to popular education institutions. One argument was that independent cultural groups were truly free and democratic, unlike those within study associations - which were somewhat regarded as semi-public corporations. ${ }^{88}$

\section{The end of a system?}

By the 1980s, the major popular education organisations - the study associations and the folk high schools-engaged in numerous activities outside of the border of the "ideal" popular education, the definition of which has been rather constant over time: largely informal learning activities for adults, without exams and grades. ${ }^{89}$ Partly because of the explicit intensions in the state subsidy system, partly due to the inherent freedom of popular education institutions to engage in all kinds of activities, a sort of tension had risen between the narrower ideal popular education and the larger organisational popular education — consisting of all those activities popular education organisations actually engaged in.

This tension became apparent in the debates preceding the 1991 reform, when it was feared that the outcome would push popular education closer to the narrower

\footnotetext{
86 SÖ-FS 1981:138, 16.
}

87 Prop. 1980/81:127, 62; SÖ-FS 1982:173; SÖ-FS 1985:111 (allowed as exemption cases); 1986:151 (permitted after approval by and accounting to SÖ); SÖ-FS 1988:131 (only approval needed); SÖ-FS 1990:62 (no approval needed).

88 E.g., Svenska Teaterförbundet and Teatercentrum, letters 1974-02-12 and 1974-02-11 to Ministry of Education and Research (U dnr 61/2/74), in: Utbildningsdepartementets arkiv (huvudarkivet), konseljakt 1974-03-08, A 1, vol. marked "Kap. 25 del 1" [Riksarkivet Marieberg]. See also joint spontaneous opinion from Danscentrum, Filmcentrum et al., June 1980, in: Utbildningsdepartementets arkiv (huvudarkivet 1975-), E1A, vol. 1435 \{regeringsakt 1981-02-19 no. 13, 5th vol.\} [Riksarkivet Arninge].

89 Gunnar Sundgren, Folkbildningsforskning - en kunskapsöversikt: Om forskningsfältets historiska bakgrund, nuläge och framtid, vol. 1 (Stockholm: Folkbildningsrådet/Mimer, 1998), 11-18. 
ideal and non-formal aspects. Therefore, representatives of folk high schools and study associations expressed the view that their wide traditions of adult education should not be thrown away. A number of folk high school teachers protested in late 1990 against what they saw as a limitation of folk high schools to strictly "popular education" means in the folk high school official report of that year. They emphasised that folk high schools span over both "adult education" and "popular education":

\footnotetext{
We want to fight for a folk high school that can develop its traditions from both adult education and popular education. The folk high school is the only option available that can in democratic forms provide study opportunities for people who have not previously been able or willing to study. ${ }^{90}$
}

In letters to school minister Göran Persson, ABF representatives expressed a similar view, stressing that the study associations had had and should continue to have a function within a wider adult education field as well. One of the ABF representatives claimed that the present policy, just as in the 1960s and 1970s when popular education had to stand back for municipal adult education, was a "state socialist" view that had no confidence in the voluntary movements. He was also of the view that the narrower idealist tradition within popular education now triumphed over the broader citizen education tradition that emphasised the values of "useful" education..$^{91}$

The 1991 reform was initially viewed as a triumph of this narrower definition of popular education. It was ruled that activities in study circles and folk high schools must clearly differ from education in formal schools and higher education. However, already in 1992, that rule was abolished for the study associations, and for the folk high schools in 1998. This decision was partly rooted in discourses of "lifelong education", purporting that popular education must freely be one of the parts in a growing educational market, not least for the unemployed. ${ }^{92}$ Thus, the tension between ideal popular education and organisational popular education, performing activities on or over the fluent borders to cultural activities, leisure activities and formal education, is still vivid.

\section{Conclusion}

This article has had a "deconstructive" purpose regarding the concept of popular education. I have argued against using it as an analytical concept-predefined by the researcher. Rather, I have made it the object of inquiry. As an analytical concept, non-formal adult education-meaning roughly the same as the ideal popular education I have discussed-would be much clearer. However, it should not be used for demarcating a certain area of activities. Instead, it could be viewed as an ideal type, which many study circles or folk high school activities would resemble (just as,

90 "Upprop för svensk folkhögskola" (1991-01-31), in: Utbildningsdepartementets arkiv (huvudarkivet 1975-), E1A, vol. 3380 \{regeringsakt 1991-02-14 no. 22, 2nd vol.\}, in the beginning of the file of U dnr 2468/90 [Riksarkivet Arninge].

91 Bosse Bergnéhr, letter 1990-10-17 to Göran Persson (U dnr 3142/90); Kent Jakobsson, letter 199010-30 to Göran Persson (U dnr 3362/90); both in: Utbildningsdepartementets arkiv (huvudarkivet 1975-), E1A, vol. 3381 \{regeringsakt 1991-02-14 no. 22, 3rd vol.\} [Riksarkivet Arninge].

92 Prop. 1991/92:157; KrU bet. 1991/92:31, SFS 1991:977, 5 §; SFS 1992:737, 5-6 \$\$; prop. 1997/98:115, 1-2, 27-29; SFS 1998:973, 6 \$; Petersen (2006); Landström (2004), 22-23, 130-40. 
for example, completely un-organised reading groups), while other ones would be considered being formal, or not for adults_or not even "education".

Swedish popular education in its organised meaning is a more historically shaped, empirically observable set of institutions - mainly study associations and folk high schools. To some extent, this also applied to libraries and other institutions that regard themselves or are regarded by others as belonging to popular education. For a long time, state funding has largely shaped both the selection of institutions and their internal organisation. That institutional structure has created a sort of logic on its own, so that large study associations perform and strive to develop those activities they have already engaged in, rather than limiting themselves to some abstract idea of "popular education" that would prohibit for example vocational training.

By highlighting the actual activities that organised popular education has engaged in, I have shown that the border zones between non-formal and formal education, or between education and (what is generally understood as) cultural activities, are interesting phenomena in themselves. Organised popular education has been an important agent in formal education, as well as in youth and cultural activities, and those aspects ought to be even more illuminated in future research. 


\section{References}

\section{Archival sources}

Riksarkivet (Arninge) [Swedish National Archives]

Folkbildningsförbundet med föregångares arkiv. Sub-fonds used:

- 03 Samverkande Bildningsförbunden.

Skolöverstyrelsens arkiv. Sub-fonds and sub-sub-fonds used:

- 05 Folkskoleavdelningen.

- 08 Undervisningsavdelningen.

- 83-03 V-avdelningen, Enheten för studieförbund.

Utbildningsdepartementets arkiv 1975-.

Riksarkivet (Marieberg) [Swedish National Archives]

Ecklesiastikdepartementets (Utbildningsdepartementets) arkiv -1974. (The name was changed from Ecklesiastikdepartementet to Utbildningsdepartementet in 1968.)

\section{Official print (with abbreviations)}

$\mathrm{AK}=$ Andra kammaren (second chamber of the Swedish parliament, existing until 1970).

ASÖ = Aktuellt från Skolöverstyrelsen (an SÖ publication, primarily with various regulations).

FK = Första kammaren (first chamber of the Swedish parliament, existing until 1970).

KrU bet. = Kulturutskottets betänkande (report from the parliamentary committee of culture, that processed some bills and motions in popular educational matters from 1971).

mot. $=$ motion (parliamentary motion).

prop. $=$ proposition $($ government bill).

rskr. = riksdagens skrivelse (confirming decisions in the Swedish parliament).

$\mathrm{SFS}=$ Svensk Författningssamling (laws and ordinances).

SOU = Statens offentliga utredningar (Swedish government official reports; the ones used are also specified under "Other references" below).

SU bet. = Statsutskottets betänkande (report from the parliamentary committee of the state, that processed most bills and motions in popular educational matters until 1970).

SÖ-FS = Skolöverstyrelsens Författningssamling (delegated legislation from SÖ).

UbU bet. = Utbildningsutskottets betänkande (report from the parliamentary committee of education, that processed most bills and motions in popular educational matters from 1971).

\section{Other references}

ABF och Kulturrådets förslag Ny kulturpolitik. Stockholm: Arbetarnas Bildningsförbund, 1973.

Anderson, Benedict. Imagined Communities: Reflections on the Origin and Spread of Nationalism. London: Verso, 1983. 
Andersson, Bo. Folkbildning i perspektiv: Studieförbunden 1870-2000-organisering, etablering och profilering. Stockholm: LTs förlag, 1980.

Bidrag till ungdomens föreningsliv och fritidsverksamhet: Betänkande med förslag av 1953 års utredning angående stöd åt nykterhetsorganisationer och ungdomsvårdande sammanslutningar, II. Stockholm, 1953.

Bidragsvillkor och avgränsningsfrågor i studiecirkelverksamheten: Promemoria upprättad inom Utbildningsdepartementet. Utbildningsdepartementet 1970:6. Stockholm, 1970.

Billig, Michael. Banal Nationalism. London: SAGE Publications, 1995.

Bjurström, Erling. "Bildning och demokrati." In Bildning och demokrati: Nya vägar i det svenska folkbildningslandskapet, edited by Erling Bjurström and Tobias Harding, 11-119, 279-82. Stockholm: Carlssons, 2013.

Braster, Sjaak. "The People, the Poor, and the Oppressed: The Concept of Popular Education through Time." Paedagogica Historica 47, no. 1-2 (2011), 1-14.

Broady, Donald, ed. Skolan under 1990-talet: Sociala förutsättningar och utbildningsstrategier: Rapport till kommittén Välfärdsbokslut. Uppsala: Uppsala universitet, 2000.

Crowther, Jim. "Reflections on Popular Education in the UK and Sweden." In Popular Education, Power and Democracy: Swedish Experiences and Contributions, edited by Ann-Marie Laginder, Henrik Nordvall and Jim Crowther, 259-74. Leicester: Niace, 2013.

Edquist, Samuel. Nyktra svenskar: Godtemplarrörelsen och den nationella identiteten 1879-1918. Uppsala: Uppsala universitet, 2001.

Esping-Andersen, Gøsta. The Three Worlds of Welfare Capitalism. Cambridge: Polity Press, 1990.

Fejes, Andreas, and Katherine Nicoll. Foucault and Lifelong Learning: Governing the Subject. London and New York: Routledge, 2008.

Fejes, Andreas. "Kvällsgymnasier - resultatet av ett vägval i vuxenutbildningens historia." Vägval i skolans historia 3, no. 4 (2003).

Fejes, Andreas. Constructing the Adult Learner: A Governmentality Analysis. Linköping: Linköpings universitet, 2006.

Ferrer, Alejandro Tiana. "The Concept of Popular Education Revisited - Or What Do We Talk about When We Speak of Popular Education.” Paedagogica Historica 47, no. 1-2 (2011), 15-31.

Förslag angående ändrade grunder för statsunderstöd åt anstalter för populärvetenskapliga föreläsningar avgifvet den 12 januari 1911 af tillkallade sakkunniga. Stockholm: Ivar Hæggströms boktryckeri, 1911.

Gustavsson, Bernt. Bildningens väg: tre bildningsideal i svensk arbetarrörelse 18801930. Stockholm: Wahlström \& Widstrand, 1991.

Hanushek, Eric A. et al., eds. Handbook of The Economics of Education, 4 vols. Amsterdam: North-Holland/Elsevier, 2006-11.

Hartman, Per. Att bilda med bild: En studie av de praktisk-estetiska studiecirklarnas utveckling. Linköping: Linköpings universitet, 2003.

Hartman, Per. Skola för ande och hand: En studie av folkhögskolans praktisk-estetiska verksamhet. Linköping: Linköpings universitet, 1993.

Johansson, Berndt. Government-Subsidized Adult Education in Sweden. Stockholm: Swedish Institute, 1973. 
Johansson, Inge. För folket och genom folket: Om idéer och utvecklingslinjer i studieförbundens verksamhet. Stockholm: Liber Utbildningsförlaget, 1985.

Johansson, Inge. Striden om vuxenutbildningen 1967-1970: En folkbildares försvarstal. Stockholm: ABF, 1990.

Jonsson, Pernilla, and Silke Neunsinger. Gendered Money: Financial Organization in Women's Movements, 1880-1933. New York: Berghahn Books, 2012.

Klockar Linder, My. Kulturpolitik: Formeringen av en modern kategori. Uppsala: Uppsala universitet, 2014.

Landström, Inger. Mellan samtid och tradition: Folkhögskolans identitet $i$ kursutbudets yrkesinriktning. Linköping: Linköpings universitet, 2004.

Larsson, Staffan. "Förnyelse som tradition." In Folkbildning - samtidig eller tidlös? Om innebörder över tid, edited by Ann-Marie Laginder and Inger Landström, 169-94. Linköping: Linköpings universitet, 2005.

Lindgren, Lena. Kan en filthatt stärka demokratin? Om mål och ideal i folkbildningssammanhang. Stockholm: Carlsson, 1996.

Lundh Nilsson, Fay. "Den svenska folkhögskolans yrkesinriktade utbildningar 1868-1940." In Två sidor av samma mynt? Folkbildning och yrkesutbildning vid de nordiska folkhögskolorna, edited by Fay Lundh Nilsson and Anders Nilsson, 81-110. Lund: Nordic Academic Press, 2010.

Lundin, Anna. Folkbildningsforskning som fält - från framväxt till konsolidering. Linköping: Linköpings universitet, 2008.

Mitch, David. "School Finance." In International Handbook on the Economics of Education, edited by Geraint Johnes and Jill Johnes, 260-98. Cheltenham: Edward Elgar, 2004.

Nordhaug, Odd. "Livslang læring: forskningsmessige utfordringer." In Livslang loering: En antologi om voksenopploringens mangfold og enhet, edited by Vigdis Haugerud and Jørg Kvam. Trondheim: Norsk voksenpedagogisk forskningsinstitutt, 1993.

Olofsson, Lars-Erik, and Kjell Rubenson. 1970-talets vuxenutbildningsreformer: Reflexioner kring strategier och utfall. Stockholm: Institutionen för pedagogik, Högskolan för lärarutbildning i Stockholm, 1986.

Osborne, Stephen P., ed. The Third Sector in Europe: Prospects and Challenges. London: Routledge, 2008.

Palmgren, Valfrid. Förslag angående de åtgärder, som från statens sida böra vidtagas för främjande af det allmänna biblioteksväsendet i Sverige, afgifvet den 28 september 1911. Stockholm: Ivar Hæggströms boktryckeri, 1911.

Petersen, Ann-Louise. Marknadsorientering inom folkbildningen: Fritt och frivilligt $i$ ett nytt ljus, Göteborg: Bokförlaget BAS, 2006.

Rose, Nikolas. "Governing 'Advanced' Liberal Societies." In Foucault and Political Reason: Liberalism, Neo-Liberalism and Rationalities of Government, edited by Andrew Barry, Thomas Osborne and Nikolas Rose, 37-64. London: UCL Press, 1996.

Rosén, Gull-Mari. Konst- och konsthantverkscirklar under 1970-talet: De fyra största studieförbundens syn på denna verksamhet med anledning av den nya kulturpolitiken. Umeå: Umeå universitet, 1984.

Rosenblum, Nancy L., and Robert C. Post, eds. Civil Society and Government. Princeton, N.J.: Princeton University Press, 2002. 
Rüsen, Jörn. History: Narration, Interpretation, Orientation. New York: Berghahn Books, 2005.

SOU 1924:5 - Betänkande med utredning och förslag angående det fria och frivilliga folkbildningsarbetet: Överarbetning av ett den 25 maj 1923 av Folkbildningssakkunniga avlämnat utlåtande: På nådigt uppdrag verkställd av de sakkunnigas ordförande Claes Lindskog. Stockholm, 1924.

SOU 1946:68 - Betänkande och förslag angående det fria och frivilliga folkbildningsarbetet avgivet av 1944 års folkbildningsutredning: Del 1: Allmänt folkbildningsarbete. Stockholm, 1946.

SOU 1961:44 - Folkbildningsarbete och ungdomsverksamhet: överväganden och förslag av 1960 års folkbildningsutredning. Stockholm, 1961.

SOU 1966:3 - Yrkesutbildningen: Yrkesutbildningsberedningen I. Stockholm, 1966.

SOU 1972:66 - Kulturrådet: Ny kulturpolitik: Del 1: Nuläge och förslag. Stockholm, 1972.

SOU 1974:54 - Vidgad vuxenutbildning: Uppsökande verksamhet och studiecirklar: Erfarenheter och förslag: Huvudbetänkande av kommittén för försöksverksamhet med vuxenutbildning, FÖVUX. Stockholm, 1974.

SOU 1979:85 - Folkbildning för 80-talet: Betänkande av 1975 års folkbildningsutredning. Stockholm, 1979.

Steele, Tom. Knowledge Is Power! The Rise and Fall of European Popular Educational Movements 1848-1939. Bern: Peter Lang, 2007.

Studieförbunden inför 90-talet: En analys av studieförbundens situation, verksamhet och uppgifter. Stockholm: Skolöverstyrelsen, 1988.

Sundgren, Gunnar. Folkbildningsforskning - en kunskapsöversikt: Om forskningsfältets historiska bakgrund, nuläge och framtid, vol. 1. Stockholm: Folkbildningsrådet/Mimer, 1998.

Sundgren, Per. Kulturen och arbetarrörelsen: Kulturpolitiska strävanden från August Palm till Tage Erlander. Stockholm: Carlsson, 2007.

Swensson, Sven. "Folkhögskolan och myndigheterna." In Svensk folkhögskola 100 år, vol. 1, 135-300. Stockholm: Liber, 1968.

Toepler, Stefan. "Government Funding Policies." In Handbook of Research on Nonprofit Economics and Management, edited by Bruce A. Seaman and Dennis R. Young, 320-34. Cheltenham: Edward Elgar, 2010.

Törnqvist, Ingvar. Oscar Olsson folkbildaren: I synnerhet hans tankar om universitetens roll i folkbildningsarbetet. Stockholm: Sober, 1996.

Torstendahl, Rolf. Bureaucratisation in Northwestern Europe, 1880-1985: Domination and Governance. London: Routledge, 1991.

Trägårdh, Lars, ed. State and Civil Society in Northern Europe: The Swedish Model Reconsidered. New York: Berghahn Books, 2007.

Tøsse, Sigvart. "Adult Education Trends and Reforms." In Reforms and Policy: Adult Education Research in Nordic Countries, 5-22. Trondheim: Tapir Academic Press, 2000.

Åkerstedt, Jonas. Den litterate arbetaren: Bildningssyn och studieverksamhet i ABF 1912-1930. Uppsala: Uppsala universitet, 1967. 